\title{
Mulch Type, Mulch Depth, and Rhizome Planting Depth for Field-grown American Mayapple
}

\author{
Kent E. Cushman ${ }^{1}$ and Muhammad Maqbool \\ North Mississippi Research and Extension Center, 5421 Highway 145 South, \\ Verona, MS 38879
}

Patrick D. Gerard ${ }^{2}$

Experimental Statistics Unit, Mississippi State University, Box 9653, Mississippi

State, MS 39762

Additional index words. Podophyllum peltatum, indian mayapple, Podophyllum emodi, Podophyllum hexandrum, medicinal herb, alternative crops

\begin{abstract}
American mayapple (Podophyllum peltatum L.) is a rhizomatous herbaceous perennial found in wooded areas of eastern North America and is a source of the pharmaceutical compound podophyllotoxin. To explore the possible domestication of this species, this research examined strategies for establishing mayapple in field plantings using organic mulches. Mayapple rhizome segments were harvested from the wild and transplanted to raised beds in northern Mississippi in Fall 2001. Two types of mulch (pine bark or wheat straw), two depths of mulch $(7.5$ or $15 \mathrm{~cm})$, and two planting depths $(0$ or $5 \mathrm{~cm})$ of rhizome segments were examined in a factorial arrangement and randomized complete block design. Data were recorded during spring of 2002 and 2003. Shoot number was not affected by mulch depth, but there was a significant interaction between mulch type and rhizome planting depth. Rhizome segments planted $0 \mathrm{~cm}$ deep and covered with straw mulch produced about $30 \%$ fewer shoots compared to any of the other treatment combinations. Number of emerging shoots was also affected by year, with a $33 \%$ increase in shoots from 2002 to 2003 . Total leaf area and total leaf dry weight were not affected by mulch depth, but there was a significant three-way interaction between mulch type, rhizome planting depth, and year. During 2002, treatment combinations were not different, but during 2003 rhizome segments planted $0 \mathrm{~cm}$ deep and covered with straw mulch produced less leaf area and leaf dry weight than any of the other treatment combinations. The ratio of sexual shoots to total shoots was affected by year, with a higher ratio of sexual shoots occurring in 2002 than 2003. Grasses established in bark mulch to a greater extent than in straw mulch in 2002 , but weed control was excellent for all treatments in 2003. These results indicate that rhizome segments planted $0 \mathrm{~cm}$ deep and covered with straw mulch consistently produced fewer shoots with less leaf area and dry mass compared to any other treatment combination. We preferred bark mulch, but we can recommend either bark or straw mulch for the purpose of establishing field plantings of american mayapple in full sun as long as rhizome planting depth is $5 \mathrm{~cm}$. There was no difference between the two mulching depths used in this study; therefore, a mulch depth of $7.5 \mathrm{~cm}$ can be recommended because of its lower cost.
\end{abstract}

American mayapple (Podophyllum peltatum L.) is a rhizomatous, herbaceous perennial found in wooded areas of eastern North America and is a source of the pharmaceutical compound podophyllotoxin (Goel et al., 1998; Imbert, 1998; Pugh et al., 2001; Rahman et al., 1995). Podophyllotoxin is currently obtained from rhizomes of the indian mayapple, $P$. emodi Wall. (syn. P. hexandrum Royle), but due to destructive harvest of the plant and over-exploitation it was reported an endangered

\footnotetext{
Received for publication 15 June 2004. Accepted for publication 19 Aug. 2004. This research was supported by NRI Competitive Grant Program 71.2, Award \#2002-01525, and Specific Cooperative Agreement No. 58-6408-7-012. Approved for publication as Journal Article No. J10468 of the Mississippi Agricultural \& Forestry Experiment Station, Mississippi State University.

${ }^{1}$ Current address: Southwest Florida Research \& Education Center, 2686 SR 29 North, Immokalee, FL 34142; e-mail kecushman@ifas.ufl.edu. 2E-mail pdg1@ra.msstate.edu.
}

species (Foster, 1993; Rai et al., 2000). Leaves of american mayapple contain relatively high levels of podophyllotoxin, and it was reported that they could be used as an alternative - yet renewable-source of the compound if the species was domesticated (Canel et al., 2001; Moraes et al., 2000).

Herbicides are commonly used in commercial horticulture, but few herbicides are labeled for medicinal herbs. Bryson and Croom (1991) evaluated 32 herbicides and herbicide combinations for production of commercial wormwood (Artemisia annua L.) and reported excellent weed control without affecting artemisinin content for several of the treatment combinations. Despite these results, the herbal supplement industry requires herbs to be free of pesticide residues and prefers organicallygrown plant material.

Mulches are used to control weeds in a wide variety of plantings, especially perennial plantings, and can be used in place of herbicides. Calkins et al. (1996) compared several types of mulches with 14 herbicides and herbicide combinations for 12 species of herbaceous, field-grown perennials and reported that a 10 to $15 \mathrm{~cm}$ layer of wood chips provided the most effective weed control and produced the best quality plants. Skroch etal. (1992) reported that organic mulches reduced total weed counts by $50 \%$ compared to control plots, and pine bark mulch was more durable than hardwood bark, cedar chips, longleaf pine needles, or shortleaf pine needles. Pine bark mulch performed as well as or better than ground cover fabric in providing excellent in-row weed protection for blueberries (Norden, 1989).

According to Singh et al. (1991), weeds caused a $40 \%$ reduction in herb and oil yield in three perennial aromatic grasses. Application of organic mulch (waste pulp of citronella) at $3 \mathrm{t} \cdot \mathrm{ha}^{-1}$ provided weed control equal to that of the hand-weeded weed-free check and similar to that of several herbicide treatments. For American ginseng, oak or poplar bark-sawdust mixes used as mulches consistently produced larger roots and higher yields than wheat straw or hardwood leaf mulches (Konsler, 1982; Konsler and Shelton, 1984). Organic mulches not only control weeds but also modify the soil environment by reducing loss of soil moisture, modifying soil temperatures, decreasing soil compaction, decreasing erosion, and altering root and shoot growth (Bennett, 1982; Borland, 1990; Goldman, 1979; Meyer, 1997; Munn, 1992; Skroch et al., 1992).

Some disadvantages of organic mulches have also been reported. Davis (1994) reported bacterial soft rot (Erwinia spp.) increased when sweet and bush basils were grown with wheat straw mulch. Weed control, however, was reported as acceptable for all treatments: black polyethylene, wheat straw, hardwood bark, or mixed wood chips. Svenson and Witte (1989) reported chlorosis, leaf scorch, and plant mortality caused by sour mulch; that is, mulch that had produced toxic substances such as methanol, acetic acid, ammonia gas, or hydrogen sulfide gas. Too much moisture, trapped undermulches, can encourage infestations of slugs and development of fungal diseases (Bennett, 1982).

The purpose of the research reported here was to 1) explore methods of establishing American mayapple under field conditions, and 2) produce weed-free plantings using organic mulches while using few, if any, herbicides. This research was part of a larger effort to explore the domestication of mayapple for use by growers of specialty crops serving the pharmaceutical industry (Cushman et al., 2005; Cushman and Maqbool, 2005; Moraes et al., 2000).

\section{Materials and Methods}

Mayapple rhizomes were harvested from the wild at a location near Holly Springs, Miss., on 31 Oct. $2001\left(34.821^{\circ} \mathrm{N}, 89.438^{\circ} \mathrm{W}\right.$, elevation $167 \mathrm{~m})$. The location of the wild population was in full sun and situated between a highly eroded drainage area and agricultural land used for the annual production of row crops. Mayapple and red buckeye (Aesculus pavia L.) dominated the site during spring and kudzu [Pueraria montana (Lour.) Merr. var. lobata 
(Willd.) Maesen \& S.M. Almeida] dominated during summer and fall. Rhizome segments were separated into four groups based on size for the purpose of blocking: extra large, large, medium, and small. Length of rhizome segments ranged from 5 to $7.5 \mathrm{~cm}$ for small-sized rhizomes to 18 to $20 \mathrm{~cm}$ for extra-large-sized rhizomes. Segments were then transplanted into raised beds at the Horticulture Research and Education Unit in Verona, Miss., on 1 Nov. 2001. The soil at Verona is a Quitman fine sandy loam (fine-loamy, siliceous, thermic, Aquic Paleudult) and was $\mathrm{pH}$ 6.5.

Treatments consisted of two mulch types (pine bark or wheat straw), two mulch depths $(7.5$ or $15 \mathrm{~cm})$, and two planting depths of rhizome segments $(0$ or $5 \mathrm{~cm})$. A $2 \times 2 \times 2$ factorial arrangement of treatments was used in a randomized complete block design with four blocks. Blocking was arranged according to size of rhizome segments, with the largest segments placed in block one and the smallest segments in block four. Each experimental unit (plot) consisted of 12 rhizome segments, three per row arranged in four parallel rows spaced $15 \mathrm{~cm}$ apart on top of raised beds. Raised beds were prepared with a press-pan-type bed shaper and spaced $1.8 \mathrm{~m}$ apart, center to center. Beds were formed $15 \mathrm{~cm}$ high and $75 \mathrm{~cm}$ wide across the top. Drip irrigation tubing was installed in the middle of each bed. Rhizomes were planted $15 \mathrm{~cm}$ apart within each parallel row. Rhizomes were centered in plots that were 1.2 $\mathrm{m}$ long. Mulch treatments were applied to the entire $1.2-\mathrm{m}$ plot immediately after transplant of rhizome segments. Plots were watered after transplant.

During Spring 2002, it was observed that the finely ground bark mulch used for bark mulch treatments (particle size 0 to $1.0 \mathrm{~cm}$ ) was too easily washed away by rain. Therefore, on 31 Oct. 2002 the fine mulch was replaced with a more coarsely ground pine bark mulch (particle size 1.0 to $2.5 \mathrm{~cm}$ ). Also at this time, the 7.5 and $15 \mathrm{~cm}$ depths of bark and straw mulch were reestablished to compensate for loss of mulch depth (settling) that had occurred over a period of about 1 year. The pine bark mulch was obtained from a commercial source and consisted of bark and wood chips from southern yellow pine species.
A datalogger (LI-1000; LI-COR, Lincoln, Nebr.) was installed on 21 Feb. 2002 and 6 Feb. 2003 to record soil temperatures for each treatment during each growing season. Thermocouples were placed in the center of the plot at a depth equal to the original depth of the rhizome segment, either 0 or $5 \mathrm{~cm}$ below the soil surface depending on treatment. The data logger was equipped with a capacity to record a maximum of five channels of temperature data. Therefore, soil temperature was monitored for only four treatment combinations (Fig. 1). The fifth thermocouple was placed $15 \mathrm{~cm}$ above ground level to record ambient air temperature.

During the 2002 growing season, weeds that had established during winter were killed with glyphosate $\left(4.5 \mathrm{~kg} \cdot \mathrm{ha}^{-1}\right)$ applied $17 \mathrm{Feb}$. before mayapple shoots had emerged. Weeds that had established during spring were not controlled as long as mayapple plants were emerging, growing, or senescing. Instead, these weeds were killed with glyphosate applied 8 July after all mayapple shoots had senesced. In 2003, the same weed control strategy was applied on 28 Feb. and again on 25 June. To control damage caused by black cutworm (Agrotis ipsilon Hufnagel), beds were sprayed with diazinon $\left(2.2 \mathrm{~kg} \cdot \mathrm{ha}^{-1}\right)$ on 12 and $25 \mathrm{Mar}$. Brodifacoum $0.005 \%$ rodent bait (d-CON; Reckitt \& Colman Inc., Wayne, N.J.) was used once in 2002 to control voles (Microtus sp.). Voles were not a problem in 2003.

Damage by wind was observed during the 2002 growing season. Therefore, windbreaks were installed on 20 Mar. 2003 for the second growing season. Construction fabric made of a 90-cm-wide woven plastic material, known as silt fencing with wooden $\mathrm{T}$ stakes, was placed adjacent to the experimental area. This helped to minimize wind damage to mayapple leaves during 2003. As rains diminished and temperatures increased each spring, drip irrigation was applied as needed to keep beds moist but not wet. Plantings were fertilized at a low rate on 18 Apr. 2002 and 2 Apr. 2003 with soluble fertilizer $(20 \mathrm{~N}-8.7 \mathrm{P}-16.6 \mathrm{~K})$ at the rate of $4.4 \mathrm{~kg} \cdot \mathrm{ha}^{-1} \mathrm{~N}$ delivered through the irrigation tubing.

Numbers of emerging shoots were recorded during March and April. Leaves were removed from shoots as they began to senesce, as evidenced by yellowing of the margins, from the fourth week of April to the third week of May in 2002 or from the third week of April to the second week of May in 2003. Shoot height was recorded just before removing leaves by measuring from the uppermost surface of the mulch to the point where the stem attached to the leaf blade. Leaf area was measured using an area meter(LI-3100; LI-COR). Leaves were dried in a forced-air, constant-temperature oven (model 1380FM; VWR Scientific Products, Cornelius, Ore.) at $60{ }^{\circ} \mathrm{C}$ and dry weight was recorded. Grass, sedge, and broadleaf weeds were collected from each plot at the end of May 2002, identified, and dried in the oven as described above and dry weights were recorded. Few broadleaf weeds were present; therefore, their numbers were not included in the statistical analysis. Very few weeds were observed during the 2003 growing season and their numbers and dry mass were not recorded. Changes in mulch depth during each growing season were determined by recording mulch depth of each plot on 19 June 2002 and 9 June 2003 after all mayapple shoots had senesced.

Data were analyzed using the Mixed procedure of SAS (8.02) (SAS Institute Inc., Cary, N.C.). Number of shoots in each plot varied from 6 to 28, and means were calculated for each parameter before statistical analysis. Least square means were used to compare treatment combinations in the event of significant interactions. Least significant differences (LSD) were calculated from the average of the standard error of each pairwise comparison given by the LSMEANS statement in SAS. Proportional data, that is, the ratio of sexual shoots to total shoots per plot, were transformed before analysis by dividing the ratio by 100 and then calculating the arcsine square root value. Being perennial plantings, plots were not rerandomized each year. Instead, year was considered a repeated measure factor in the analyses.

\section{Results}

Rhizome segments experienced daily fluctuations in temperature, but these fluctuations were of a much lower magnitude than that of air temperature (Fig. 1). Rhizome segments

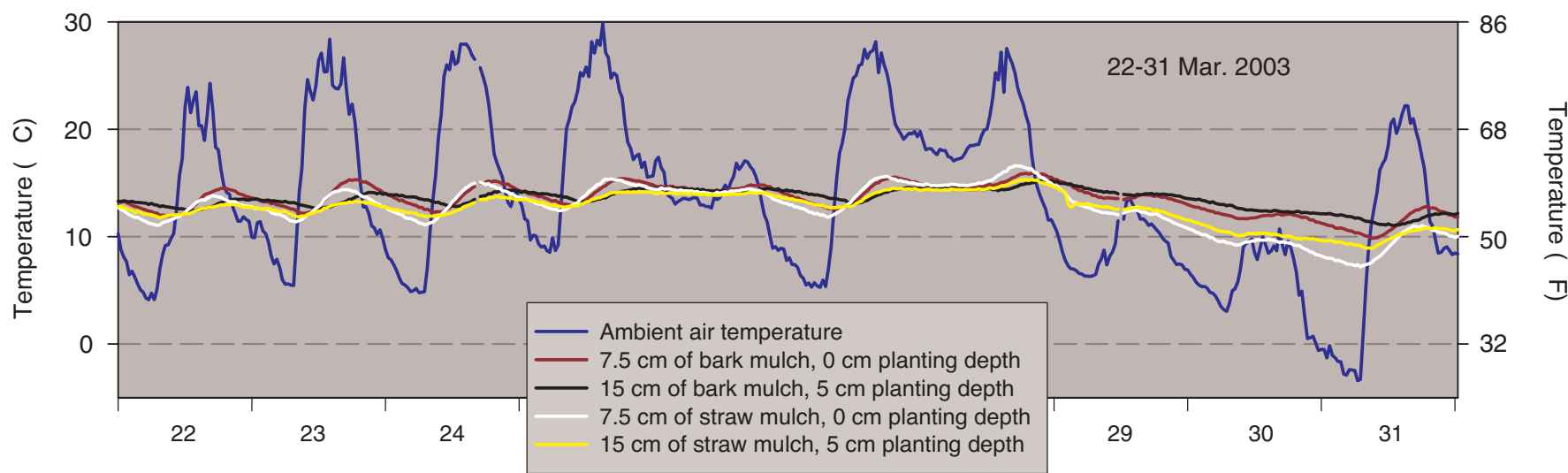

Fig. 1. Example of soil and ambient air temperatures patterns recorded in this study. Temperatures shown were recorded during the last $10 \mathrm{~d}$ of March 2003 and show selected combinations of mulch type, mulch depth, and rhizome planting depth. Soil temperatures were measured at the depth of planting of mayapple rhizome propagules. Air temperature was measured $15 \mathrm{~cm}$ above soil surface. 
Table 1. Probability table for effects of mulch type, mulch depth, rhizome planting depth, and year on number of shoots, total leaf area, total dry weight, shoot height, and ratio of sexual shoots to total shoots of american mayapple. Study was conducted in 2002 and 2003.

\begin{tabular}{|c|c|c|c|c|c|c|}
\hline Factor & $\begin{array}{l}\text { Shoots } \\
\text { (no/plot) }\end{array}$ & $\begin{array}{c}\text { Total } \\
\text { leaf area } \\
\left(\mathrm{cm}^{2}\right)\end{array}$ & $\begin{array}{c}\text { Total leaf } \\
\text { dry wt } \\
(\mathrm{g})\end{array}$ & $\begin{array}{c}\text { Shoot } \\
\text { ht } \\
(\mathrm{cm})\end{array}$ & Ratio $^{z}$ & $\begin{array}{c}\text { Transformed } \\
\text { Ratio }\end{array}$ \\
\hline Mulch type (mt) & 0.0162 & 0.0112 & 0.0055 & 0.0017 & 0.3066 & 0.2259 \\
\hline Mulch depth (md) & 0.3178 & 0.0746 & 0.1443 & 0.0248 & 0.5808 & 0.3791 \\
\hline $\mathrm{mt} \times \mathrm{md}$ & 0.4350 & 0.4012 & 0.4364 & 0.0007 & 0.6449 & 0.8355 \\
\hline Planting depth (pd) & 0.0082 & 0.1203 & 0.0785 & 0.0013 & 0.9598 & 0.5046 \\
\hline $\mathrm{mt} \times \mathrm{pd}$ & $0.0191^{y}$ & 0.0096 & 0.0056 & 0.0001 & 0.1595 & 0.0668 \\
\hline $\mathrm{md} \times \mathrm{pd}$ & 0.6810 & 0.9139 & 0.8752 & 0.2902 & 0.9994 & 0.8810 \\
\hline $\mathrm{mt} \times \mathrm{md} \times \mathrm{pd}$ & 0.2842 & 0.2572 & 0.1744 & 0.0313 & 0.4638 & 0.7243 \\
\hline Year (yr) & 0.0001 & $<0.0001$ & $<0.0001$ & $<0.0001$ & 0.0003 & 0.0003 \\
\hline $\mathrm{yr} \times \mathrm{mt}$ & 0.0517 & 0.0076 & 0.0136 & $<0.0001$ & 0.3993 & 0.3869 \\
\hline $\mathrm{yr} \times \mathrm{md}$ & 0.3255 & 0.3468 & 0.2198 & 0.6182 & 0.7531 & 0.8396 \\
\hline $\mathrm{yr} \times \mathrm{mt} \times \mathrm{md}$ & 0.9683 & 0.8174 & 0.6650 & 0.0382 & 0.5695 & 0.8336 \\
\hline $\mathrm{yr} \times \mathrm{pd}$ & 0.0713 & 0.6966 & 0.5854 & 0.9029 & 0.5506 & 0.4713 \\
\hline $\mathrm{yr} \times \mathrm{mt} \times \mathrm{pd}$ & 0.1977 & 0.0106 & 0.0156 & 0.1079 & 0.6979 & 0.8025 \\
\hline $\mathrm{yr} \times \mathrm{md} \times \mathrm{pd}$ & 0.6065 & 0.9366 & 0.9009 & 0.7898 & 0.5810 & 0.5853 \\
\hline $\mathrm{yr} \times \mathrm{mt} \times \mathrm{md} \times \mathrm{pd}$ & 0.4530 & 0.3959 & 0.4307 & 0.8874 & 0.3660 & 0.2852 \\
\hline
\end{tabular}

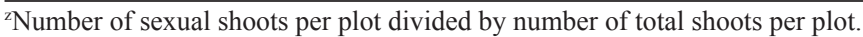

${ }^{\text {y }}$ Significant main effects and their interactions $(P \leq 0.05)$ are in bold and presented in subsequent tables.

Table 2. Number of shoots of american mayapple as affected by year and the interaction of mulch depth and planting depth during 2002 and 2003.

\begin{tabular}{lcccc}
\hline $\begin{array}{l}\text { Mulch } \\
\text { type }\end{array}$ & $\begin{array}{c}\text { Mulch } \\
\text { depth } \\
(\mathrm{cm})\end{array}$ & $\begin{array}{c}\text { Planting } \\
\text { depth } \\
(\mathrm{cm})\end{array}$ & Year & $\begin{array}{c}\text { Total } \\
\text { shoots } \\
(\mathrm{no} / \mathrm{plot})\end{array}$ \\
\hline Bark & & 0 & & $13.5 \mathrm{a}$ \\
& & 5 & & $13.8 \mathrm{a}$ \\
Straw & 5 & & $9.3 \mathrm{~b}$ \\
& 7.5 & & 2002 & $13.8 \mathrm{a}$ \\
& 15.0 & & 2003 & 13.0 \\
& & & $10.8 \mathrm{~b}$ \\
& & & $14.4 \mathrm{a}$ \\
\hline
\end{tabular}

${ }^{\mathrm{z}}$ Values are means of four replications. Values in column followed by the same lowercase letters were not significantly different at $P \leq 0.05$.

Table 3. Leaf area and leaf dry weight of american mayapple as affected by mulch depth and the interaction of mulch type, planting depth and year during 2002 and 2003.

\begin{tabular}{|c|c|c|c|c|c|}
\hline $\begin{array}{l}\text { Mulch } \\
\text { type }\end{array}$ & $\begin{array}{c}\text { Mulch } \\
\text { depth } \\
(\mathrm{cm})\end{array}$ & $\begin{array}{c}\text { Planting } \\
\text { depth } \\
(\mathrm{cm})\end{array}$ & Year & $\begin{array}{l}\text { Leaf } \\
\text { area }^{z} \\
\left(\mathrm{~cm}^{2}\right)\end{array}$ & $\begin{array}{c}\text { Leaf } \\
\text { dry } \mathrm{wt}^{\mathrm{z}} \\
(\mathrm{g})\end{array}$ \\
\hline \multirow[t]{4}{*}{$\overline{\text { Bark }}$} & & 0 & 2002 & $1410 \mathrm{~b}$ & $6.9 \mathrm{~b}$ \\
\hline & & & 2003 & $3660 \mathrm{a}$ & $17.6 \mathrm{a}$ \\
\hline & & 5 & 2002 & $1510 \mathrm{~b}$ & $7.2 \mathrm{~b}$ \\
\hline & & & 2003 & $3010 \mathrm{a}$ & $14.7 \mathrm{a}$ \\
\hline \multirow[t]{6}{*}{ Straw } & & 0 & 2002 & $1070 \mathrm{~b}$ & $4.7 \mathrm{~b}$ \\
\hline & & & 2003 & $1520 \mathrm{~b}$ & $7.1 \mathrm{~b}$ \\
\hline & & 5 & 2002 & $1550 \mathrm{~b}$ & $7.3 \mathrm{~b}$ \\
\hline & & & 2003 & $3010 \mathrm{a}$ & $14.6 \mathrm{a}$ \\
\hline & 7.5 & & & 2300 & 10.8 \\
\hline & 15.0 & & & 1890 & 9.2 \\
\hline
\end{tabular}

${ }^{z}$ Values are means of four replications. Values in columns followed by the same lowercase letters were not significantly different at $P \leq 0.05$.

covered with bark mulch experienced slightly less variation in temperature than segments covered with straw mulch. Regardless of mulch type, rhizome segments planted $5 \mathrm{~cm}$ deep and covered to a depth of $15 \mathrm{~cm}$ of mulch appeared to have experienced less variation in temperature than rhizome segments planted $0 \mathrm{~cm}$ deep and covered to a depth of $7.5 \mathrm{~cm}$ of mulch.

Number of emerging shoots was not affected by mulch depth, but there was a significant interaction between mulch type and rhizome planting depth (Table 1). Rhizome segments planted $0 \mathrm{~cm}$ deep and covered with straw mulch produced about $30 \%$ fewer shoots than any of the other treatment combinations (Table 2). Numbers of shoots were also significantly affected by year (Table 1) and increased by $33 \%$ from 2002 to 2003 (Table 2).

Total leaf area and total leaf dry weight were not affected by mulch depth, but there was a significant three-way interaction between mulch type, rhizome planting depth, and year (Table 1). Three out of four treatment combinations produced significantly greater leaf area and leaf dry weight in 2003 compared to 2002 . The only treatment combination that did not increase from 2002 to 2003 was the 0 $\mathrm{cm}$ planting depth in combination with straw mulch. It produced about $50 \%$ or less leaf area and leaf dry mass than that of the other three treatment combinations in 2003 (Table 3 ). During 2002, treatment combinations were not significantly different.

There were two significant three-way interactions for shoot height (Table 1). The first three-way interaction was among mulch type, mulch depth, and rhizome planting depth. Shoots were tallest for three treatment combinations: $7.5 \mathrm{~cm}$ of bark mulch in combination with rhizomes planted 0 or $5 \mathrm{~cm}$ deep and $7.5 \mathrm{~cm}$ of straw mulch in combination with rhizomes planted $5 \mathrm{~cm}$ deep. Shoots were shortest for one treatment combination: $7.5 \mathrm{~cm}$ of straw mulch in combination with rhizomes planted $0 \mathrm{~cm}$ deep (Table 4). The second three-way interaction was among mulch type, mulch depth, and year. Two treatment combinations in $2003,7.5 \mathrm{~cm}$ of bark mulch or $15 \mathrm{~cm}$ of straw mulch, produced the tallest shoots and two treatment combinations in $2002,7.5 \mathrm{~cm}$ or $15 \mathrm{~cm}$ of straw mulch, produced the shortest shoots (Table 4).

Ratios of sexual shoots to total shoots were not affected by mulch type, mulch depth, or rhizome planting depth (Table 1). However, ratios were significantly affected by year, decreasing by $77 \%$ from 2002 to 2003 (Table 5). A similar trend was observed with the transformed data.

Treatments influenced weed populations in 2002 but not in 2003 . There was a significant interaction between mulch type and mulch depth for number of grass weeds at the end of the 2002 growing season (Table 6) (Cushman et al., 2003). Grasses did not establish in straw mulch, but in bark mulch more grasses established in the $7.5 \mathrm{~cm}$ depth than in the 15 $\mathrm{cm}$ depth (Table 6). The number of sedges, as well as total dry weight of all weeds, was not affected by mulch type, mulch depth, or rhizome planting depth. In 2003, weed control was excellent and weeds were too few to record.

In 2002, 7 months after installation of the mulch treatments, $80 \%$ and $86 \%$ of the original 7.5 and $15 \mathrm{~cm}$ depths, respectively, of wheat straw remained intact. In contrast, $57 \%$ and $55 \%$ of the original 7.5 and $15 \mathrm{~cm}$ depths, 
respectively, of bark mulch remained intact (Table 6) (Cushman et al., 2003). In 2003, seven months after reestablishing the original mulch depths, $97 \%$ and $70 \%$ of the restored 7.5 and $15 \mathrm{~cm}$ depths, respectively, of wheat straw remained intact (data not shown). In contrast, $97 \%$ and $88 \%$ of the restored 7.5 and $15 \mathrm{~cm}$

Table 4. Shoot height of american mayapple as affected by two three-way interactions during 2002 and 2003.

\begin{tabular}{|c|c|c|c|c|}
\hline $\begin{array}{l}\text { Mulch } \\
\text { type }\end{array}$ & $\begin{array}{l}\text { Mulch } \\
\text { depth } \\
(\mathrm{cm})\end{array}$ & $\begin{array}{c}\text { Planting } \\
\text { depth } \\
(\mathrm{cm})\end{array}$ & Year & $\begin{array}{c}\text { Shoot } \\
\mathrm{ht}^{\mathrm{z}} \\
(\mathrm{cm})\end{array}$ \\
\hline \multirow[t]{4}{*}{$\overline{\text { Bark }}$} & 7.5 & 0 & & $16.1 \mathrm{a}$ \\
\hline & & 5 & & $15.4 \mathrm{ab}$ \\
\hline & 15.0 & 0 & & $13.7 \mathrm{~cd}$ \\
\hline & & 5 & & $13.8 \mathrm{~cd}$ \\
\hline \multirow[t]{4}{*}{ Straw } & 7.5 & 0 & & $11.5 \mathrm{e}$ \\
\hline & & 5 & & $15.2 \mathrm{ab}$ \\
\hline & 15.0 & 0 & & $13.1 \mathrm{~d}$ \\
\hline & & 5 & & $14.7 \mathrm{bc}$ \\
\hline \multirow[t]{4}{*}{ Bark } & 7.5 & & 2002 & $15.1 \mathrm{bc}$ \\
\hline & & & 2003 & $16.4 \mathrm{a}$ \\
\hline & 15.0 & & 2002 & $13.9 \mathrm{~cd}$ \\
\hline & & & 2003 & $13.6 \mathrm{~d}$ \\
\hline \multirow[t]{4}{*}{ Straw } & 7.5 & & 2002 & $11.8 \mathrm{e}$ \\
\hline & & & 2003 & $15.0 \mathrm{bc}$ \\
\hline & 15.0 & & 2002 & $11.8 \mathrm{e}$ \\
\hline & & & 2003 & $16.0 \mathrm{ab}$ \\
\hline
\end{tabular}

${ }^{2}$ Values are means of four replications. Values in column followed by the same

lowercase letters were not significantly different at $P \leq 0.05$.

Table 5. Ratio of number of sexual shoot to total shoots of american mayapple as influenced by mulch type, mulch depth, or planting depth during 2002 and 2003.

\begin{tabular}{|c|c|c|c|c|}
\hline $\begin{array}{l}\text { Mulch } \\
\text { type }\end{array}$ & $\begin{array}{l}\text { Mulch } \\
\text { depth } \\
(\mathrm{cm})\end{array}$ & $\begin{array}{c}\text { Planting } \\
\text { depth } \\
(\mathrm{cm})\end{array}$ & Year & Ratio $^{z}$ \\
\hline Bark & & & & 16.7 \\
\hline \multirow[t]{7}{*}{ Straw } & & & & 12.1 \\
\hline & 7.5 & & & 15.6 \\
\hline & 15.0 & & & 13.2 \\
\hline & & 0 & & 14.3 \\
\hline & & 5 & & 14.5 \\
\hline & & & 2002 & $23.5 \mathrm{a}$ \\
\hline & & & 2003 & $5.3 \mathrm{~b}$ \\
\hline
\end{tabular}

${ }^{2}$ Values are means of four replications. Values in column followed by the same lowercase letters were not significantly different at $P \leq 0.05$. Percent data were transformed before analysis by dividing by 100 and then calculating the arcsine square root transformation. Analysis of transformed data not shown because results were identical to that of percent data. during early spring, when light frosts occurred, stems of mayapple shoots arising from straw mulch were slightly damaged while those in bark were not. Stems became discolored only in a small area where the stem came in contact with the uppermost layer of the straw mulch. Straw mulch also had a tendency to hinder the emergence of sexual shoots. Sexual shoots have two leaves and a forked stem. The forked stem would sometimes become entangled in the straw mulch during emergence. Shoots from all plots, regardless of treatment, experienced early-season wind damage, especially during 2002 when windbreaks were absent.

\section{Discussion}

Mulch type and rhizome planting depth clearly affected emergence and growth of American mayapple, with the treatment combination of straw mulch and $0 \mathrm{~cm}$ planting depth producing fewer shoots with less total leaf area and total leaf dry weight compared to any of the other treatment combinations. Rhizomes planted to this treatment appeared to be exposed to a greater magnitude in dayto-day temperature fluctuations than the other treatment combinations, indicating that this treatment provided the least protection. This lower level of protection may have exposed rhizomes to greater levels of temperature stress and possibly moisture stress compared to other treatments.

Although mulch depth had no influence on emergence and growth of mayapple shoots, shoot height was affected when mulch depth interacted with mulch type, rhizome planting depth, and year. These interactions were complicated, with two significant three-way interactions. We observed in several other of our American mayapple studies (unpublished data) that the tallest shoots tended to be the most vigorous plants with the greatest leaf areas and leaf dry weights. It is possible, therefore, that treatments that affected plant vigor probably affected plant height. Confounding this effect is how mulches affected plant height. Straw

Table 6. Number of grass and sedge weeds, weed dry weight, and final mulch depth of american mayapple in 2002. Two types of mulch (bark mulch or wheat straw), two mulch depths $(7.5 \mathrm{~cm}$ or $15 \mathrm{~cm})$ and two planting depths $(0 \mathrm{~cm}$ or $5 \mathrm{~cm})$ were used.

\begin{tabular}{|c|c|c|c|c|c|c|}
\hline $\begin{array}{l}\text { Mulch } \\
\text { type }\end{array}$ & $\begin{array}{l}\text { Mulch } \\
\text { depth } \\
(\mathrm{cm})\end{array}$ & $\begin{array}{c}\text { Planting } \\
\text { depth } \\
(\mathrm{cm})\end{array}$ & $\begin{array}{l}\text { Grasses }^{2} \\
\text { (no/plot) }\end{array}$ & $\begin{array}{c}\text { Sedges } \\
\text { (no/plot) }\end{array}$ & $\begin{array}{l}\text { Weed } \\
\text { dry wt } \\
\text { (g/plot) }\end{array}$ & $\begin{array}{c}\text { Final } \\
\text { mulch } \\
\text { depth }^{y} \\
(\mathrm{~cm})\end{array}$ \\
\hline \multirow{2}{*}{ Straw } & 7.5 & & & 1.3 & 0.7 & \\
\hline & 15.0 & & & 2.8 & 1.5 & \\
\hline Straw & 7.5 & & $0.0 \mathrm{~b}$ & & & $6.0 \pm 0.4$ \\
\hline \multirow[t]{3}{*}{ Straw } & 15.0 & & $0.0 \mathrm{~b}$ & & & $12.9 \pm 0.7$ \\
\hline & & 0 & 3.3 & 2.2 & 1.7 & $8.0 \pm 0.9$ \\
\hline & & 5 & 3.1 & 1.9 & 0.5 & $7.7 \pm 1.0$ \\
\hline mt (mulch type) & & & 0.0001 & 0.1427 & 0.1021 & \\
\hline md (mulch depth) & & & 0.0216 & 0.5354 & 0.5263 & \\
\hline $\mathrm{mt} \times \mathrm{md}$ & & & 0.0216 & 0.4704 & 0.4737 & \\
\hline
\end{tabular}

${ }^{2}$ Values are means of four replications. Values in column followed by the same lowercase letters were not significantly different at $P \leq 0.05$. Ns not significant. 
mulch tended to produce shorter shoots than bark mulch. This was due to straw mulch being less dense than bark mulch, and shoots arising from straw mulch were exposed to light before reaching the uppermost surface of the mulch. As a result, shoot height was probably shortened compared to bark mulch.

Year was an important factor in our study. Shoot number increased from 2002 to 2003, indicating that rhizomes used in this study had established and were producing increasing numbers of growing points. In contrast, the ratio of sexual shoots to total shoots decreased from 2002 to 2003, indicating that these rhizomes had declined in reproductive vigor. The ratio of sexual shoots to total number of shoots in a given area may be an indication of the overall vigor of mayapple plantings. Vigorous mayapple colonies in the wild appear denser, with more shoots per unit area, and more sexually productive, with a higher ratio of sexual shoots in the population, than colonies that appear weak (unpublished data). During the two years of this study, mayapple rhizomes increased in vegetative growth at the expense of sexual vigor.

One of the many purposes of organic mulches, and one of the main purposes of this research, is to minimize or prevent weed growth. In 2002, straw mulch performed better than bark mulch for control of grass weeds and for retaining mulch depth over time. However, when the finely ground bark mulch used in 2002 was replaced with coarsely ground bark mulch in 2003, there were no differences between the straw and bark mulches for weed control or retention of mulch depth. Mulches were not fumigated before use in this study; therefore, the mulches themselves may have been a source of weed seeds.

In conclusion, we recommend bark or straw mulch in combination with a rhizome planting depth of $5 \mathrm{~cm}$ for the purpose of establishing field plantings of American mayapple in full sun. Bark mulch should be a coarsely-ground material. Mulching depth of $7.5 \mathrm{~cm}$ was adequate for weed control when used in combination with glyphosate applications before mayapple emergence to eliminate established winter weeds and after senescence to eliminate established spring and summer weeds. Mulching depth of $7.5 \mathrm{~cm}$ was also adequate for retention of mulch depth over time and providing for successful establishment and growth of mayapple rhizome propagules. Under our growing conditions, we preferred the bark mulch to the straw mulch but, regardless of the type, we recommend using no less than a $7.5 \mathrm{~cm}$ layer. We do not recommend a rhizome planting depth of $0 \mathrm{~cm}$.

\section{Literature cited}

Bennett, J. 1982. Starting up: Mulches to retain moisture and cool the soil. Horticulture p. 55-56.

Borland, J. 1990. Mulch: Examining the facts and fallacies behind the uses and benefits of mulch. Amer. Nurseryman 172:132-143.

Bryson, C.T. and E.M. Croom, Jr. 1991. Herbicide inputs for a new agronomic crop, annual wormwood (Artemesia annua). Weed Technol. 5:117-124.

Calkins, J.B., B.T. Swanson, and D.L. Newman. 1996. Weed control strategies for field grown herbaceous perennials. J. Environ. Hort. 14:221-227.

Canel, C., F.E. Dayan, M. Ganzera, I.A. Khan, A Rimando, C.L. Burandt, Jr., and R.M. Moraes. 2001. High yield of podophyllotoxin from leaves of Podophyllum peltatum by in situ conversion of podophyllotoxin 4- $O-\beta-D$-glucopyranoside. Planta Med. 67:97-99.

Cushman, K.E., M. Maqbool, and R.M. Moraes. 2003. Mulch type, mulch depth, and planting depth for field-grown mayapple: First-year results. Annu. Rpt. 2002 N. Miss. Res. Ext. Ctr., Miss. Agr. For. Expt. Sta. Info. Bul. 398:351-357.

Cushman, K.E., M. Maqbool, H. lata, E. Bedir, I.A. Khan, and R.M. Moraes. 2005. Podophyllotoxin content and yield of american mayapple leaves in sun and shade. HortScience 40:60-63.

Cushman, K.E. and M. Maqbool. 2005. Propagule type and planting time affect subsequent mayapple growth. HortScience (in press).

Davis, J.M. 1994. Comparison of mulches for fresh-market basil production. HortScience 29:267-268.

Foster, S. 1993. Medicinal plant conservation and genetic resources: Examples from the temperate Northern hemisphere. Acta Hort. 330:67-73.

Goel, H.C., J. Prasad, A. Sharma, and B. Singh. 1998. Antitumour and radioprotective action of Podophyllum hexandrum. Indian J. Expt. Biol. 36:583-587.
Goldman, M.C. 1979. The many moods of mulch: From keeping down weeds to keeping up soil moisture and yields, it's a good mulch that makes the big difference! Organic Gardening 26:64-70.

Imbert, T.F. 1998. Discovery of podophyllotoxin. Biochimie 80:207-222.

Konsler, T.R. 1982. Some responses of american ginseng (Panax quinquefolium L.) to kind of bed mulch and to plant spacing through four growing seasons. Proc. 4th Natl. Ginseng Conf., Lexington, Ky. 4:14-24.

Konsler, T.R and J.E. Shelton. 1984. Plant spacing, mulches and soil effects on cultivated American ginseng (Panax quinquefolium). Proc. 6th N. Amer. Ginseng Conf., Guelph, Ont. 6:23-49.

Meyer, S. 1997. Complete guide to organic mulch. Organic Gardening 44:50-55.

Moraes, R.M., C. Burandt, Jr., M. Ganzera, X. Li, I. Khan, and C. Canel. 2000. The american mayapple revisited-Podophyllum peltatum — still a potential cash crop? Econ. Bot. 54:471-476.

Munn, D.A. 1992. Comparisons of shredded newspaper and wheat straw as crop mulches. HortTechnology 2:361-366.

Norden, D.E. 1989. Comparison of pine bark mulch and polypropylene fabric ground cover in blueberries. Proc. Fla. State. Hort. Soc. 102:206-208.

Pugh, N., I.A. Khan, R.M. Moraes, and D.S. Pasco. 2001. Podophyllotoxin lignans enhance IL$1 \beta$ but suppress TNF- $\alpha$ mRNA expression in LPS-treated monocytes. Immunopharmacol. Immunotoxicol. 23:83-95.

Rahman, A., M. Ashraf, M.I. Choudhary, H. Rehman, and M.H. Kazmi. 1995. Antifungal aryltetralin lignans from leaves of Podophyllum hexandrum. Phytochemistry 40:427-431.

Rai, L.K., P. Prasad, and E. Sharma. 2000. Conservation threats to some important medicinal plants of the Sikkim Himalaya. Biol. Conserv. 93:27-33.

SAS Institute Inc. 2000. SAS OnlineDoc. Version 8. SAS Inst. Inc., Cary, N.C.

Singh, A., K. Singh, and D.V. Singh. 1991. Suitability of organic mulch (distillation waste) and herbicides for weed management in perennial aromatic grasses. Trop. Pest Mgt. 37:162-165.

Skroch, W.A., M.A. Powel, T.E. Bilderback, and P.H.Henry. 1992. Mulches: Durability, aesthetic value, weed control, and temperature. J. Environ. Hort. 10:43-45.

Svenson, S.E. and W.T. Witte. 1989. Mulch toxicity: Prevent plant damage by carefully processing and storing organic mulch. Amer. Nurseryman 169:45-46. 